\title{
Simulated Performance of a Renewable Energy Technology - Heat Pump Systems in Semi-Arid California Greenhouses
}

\author{
C. Hardin \\ Department of Mechanical Engineering \\ California Polytechnic State University \\ San Luis Obispo, CA 93407 \\ USA
}

\author{
T. Mehlitz, I. Yildiz and S.F. Kelly \\ Department of BioResource and \\ Agricultural Engineering \\ California Polytechnic State University \\ San Luis Obispo, CA 93407 \\ USA
}

Keywords: energy conservation, water conservation, closed greenhouse, heat pumps

\begin{abstract}
In addition to the labor, energy and water consumption are the two main cost drivers in current greenhouse systems. Consequently, considerable effort is expended to conserve energy and water, and look for alternative energy sources, especially environmentally friendly renewable energy sources and technologies. Greenhouses in hot and arid regions also require large quantities of water for irrigation. Using proper technologies and environmental management systems can significantly change the energy and moisture dynamics of greenhouse production systems. This study aims to focus on reducing natural gas, electricity, and water consumption in semi-arid California greenhouses introducing renewable energy heat pump technologies to both open and confined greenhouses in California. The confined system has no external aeration and has no need for further water supply. It has a great potential to reduce the demand for natural gas, the load on the power grid, and the demand for irrigation water in greenhouse operations. It also allows plant protection without using chemical insecticides and the accumulation of carbon dioxide without aeration losses.
\end{abstract}

\section{INTRODUCTION}

Alternative energy sources and energy conservation practices are receiving greater attention for heating, cooling and power generation applications. To provide optimal micro-environments for plant growth, producers can use or control the number of glazing layers, insulation curtains or screens to reduce long-wave radiation losses at night, reduced ventilation rates, evaporative coolers, and shading devices to control incoming solar radiation. In addition, the limited supply of fossil fuels and the uncertainty about the oil supply in recent years has advanced the potential use of heat pumps for both heating and cooling purposes (Christensen and Santoso, 1990; Yildiz et al., 1993; Willits and Gurjer, 2004; Ebru and Arif, 2007; Hamada et al., 2007; Karlsson and Fahle'n, 2007). However, these systems involve complex tradeoffs between initial and operating costs for cooling and heating in greenhouses, plant responses to various environmental factors and the strategies used to regulate temperature, humidity and $\mathrm{CO}_{2}$ levels in the crop canopy. Special attention must be given to the operational strategies, especially in maintaining acceptable relative humidity levels.

A dynamic simulation model was developed and validated to provide an accurate prediction of greenhouse energy and moisture exchanges as a function of dynamic environmental factors (Yildiz and Stombaugh, 2006a). This model was used to predict heating and cooling loads, water use, and to evaluate the operational strategies associated with heating and cooling using the proposed heat pump and a conventional system. The overall objective of this study was to compare conventional, open loop and closed loop heat pump greenhouse systems' performances in semi-arid California, with focus especially to the confined loop heat pump system. 


\section{MATERIALS AND METHODS}

\section{Weather File}

January, April, and July weather files for San Luis Obispo (35 $17^{\prime}$ N and $120^{\circ} 39^{\prime}$

W), California, USA were used to represent winter, spring, and summer in the simulations. Simulations were performed starting at the beginning of the fifth day and ended at the end of 29th day of the month providing 25-day simulations. All simulations were performed for the years 2005, 2006 and 2007.

\section{Greenhouse Characteristics, Operational and Control Strategies, and Analysis}

Using the dynamic simulation model, different greenhouse configurations were studied to determine their energy and water consumption. Table 1 shows the greenhouse and the crop characteristics used in this study. To see how different configurations of the heat pump and ventilation control affect greenhouse environmental conditions, simulations were performed under three different conditions. In a conventional greenhouse, ventilation and the crops themselves typically cool the greenhouse interior during hot days. Evaporative cooling was also provided in the conventional system to handle excess cooling loads. The heat pump system can both heat and cool keeping the inside temperature and relative humidity levels within acceptable ranges so the vegetation does not suffer from high inside relative humidity levels or low inside temperatures. In an open loop heat pump greenhouse, not only is ventilation used for cooling and for removing humidity but also one of the heat pump units acted as a dehumidifier condensing water vapor into usable water. Furthermore, the heat pump regulated inside temperature just as the conventional furnace did in the conventional system. In a closed loop heat pump system, the greenhouse was completely closed off to the outside air, allowing no ventilation for cooling or relative humidity control. Heating, cooling, ventilation and shading system specifics of the study, and the operational and control strategies were previously reported in details by Yildiz and Stombaugh (2006b). For all three years and all three seasons a total of 36 simulations were executed. Total energy and water consumption data were collected for 25-day trials. Heating, cooling, ventilation, and pump energy requirements were collected separately. Statistical analysis on these trials was performed using standard Analysis of Variance (ANOVA) (significance level of $\mathrm{P}<0.05$ ) which analyzed if a change between configurations was significant and Tukey Simultaneous Test at a confidence level of $95 \%$ to compare the means between the treatments and to find statistically significant differences.

\section{RESULTS AND DISCUSSION}

\section{Energy Consumption}

The mean energy consumption for heating (of three years) differed with the season and different systems (Fig. 1A). Naturally, the colder the outside weather condition was, the more heating energy was needed (i.e. winter the most, summer the least). For the conventional system, the average energy consumption over the three years was found to be $25.82,21.11$ and $10.95 \mathrm{MJ} / \mathrm{m}^{2} /$ day for winter, spring, and summer, respectively (Fig. 1A). For the open loop heat pump system, the average energy consumption over the three years was found to be $11.47,9.55$, and $5.53 \mathrm{MJ} / \mathrm{m}^{2} /$ day for winter, spring, and summer, respectively. For the confined loop heat pump system, the average energy consumption over the three years was $10.89,10.29$ and $12.42 \mathrm{MJ} / \mathrm{m}^{2} /$ day for winter, spring and summer, respectively. The average statistical comparisons between all possible pairs were conducted using the Tukey Simultaneous Test at a 95\% confidence level. Data for statistical analysis was taken as a whole over all season and years. Table 2 shows that all of the presented energy means were statistically different from each other. Overall, the open loop heat pump system required the least amount of energy, followed by the confined greenhouse and then finally the conventional greenhouse having the highest energy consumption. In comparison, both types of looped heat pump greenhouses 
lowered energy consumption compared against the traditional method. Upon closer analysis, the confined loop heat pump system energy requirements remained relatively stable for all seasons. This was because the closed system had low cooling requirements in winter when the heating requirements were high, and the very same system had high cooling requirements in summer when the heating requirements were low. The conventional and open systems, which were open to the outside environment, required more energy during the winter and distinctly less energy in the summer. The confined system almost always needed less energy relative to the conventional system and less energy relative to the open heat pump system in winter.

As seen, one of the main factors on the energy consumption was the outside weather condition. The presented study was executed using weather data from three different years (2005, 2006 and 2007). Differences in energy consumption between the years were not statistically significant. For the winter and spring data sets, the energy consumption increased over the years, meaning that the year 2006 was colder than 2005; and the year 2007 was even colder than 2006. The summer data proved that the coldest summer was in the year 2005 , followed by a very warm summer in 2006 , and then, relatively speaking, another cold summer in 2007. Due to the space limitations, detailed climatic information could not be provided in the article. However, for the duration of the simulation period, the mean outside temperatures of three years were $9.6,11.5$ and $16.1^{\circ} \mathrm{C}$ in winter, spring and summer, respectively; the mean solar radiation received on a horizontal plane during daytime were 272,396 and $466 \mathrm{~W} / \mathrm{m}^{2}$ in winter, spring and summer, respectively; and the mean outside relative humidity levels were 68.5, 77.3 and $80.4 \%$ in winter, spring and summer, respectively.

\section{Water Consumption}

The water consumption was significantly decreased in the closed loop heat pump greenhouse system in comparison with conventional and open loop heat pump systems. For the conventional system, the average water use for transpiration over the three years was found to be $2.32,2.12$ and $2.07 \mathrm{MJ} / \mathrm{m}^{2} /$ day for winter, spring, and summer, respectively. For the open loop heat pump system, the average water use for transpiration over the three years was found to be $2.25,2.20$ and $2.29 \mathrm{MJ} / \mathrm{m}^{2} /$ day for winter, spring, and summer, respectively. For the closed loop greenhouse system, the average water use for transpiration over the three years was $0.74,0.76$ and $1.5 \mathrm{MJ} / \mathrm{m}^{2} /$ day for winter, spring and summer, respectively. Due to the high relative humidity levels maintained within the confined system, transpiration rates were relatively lower compared to those in the other two systems. In the closed heat pump greenhouse system in all three years, especially in winters, the dehumidification system maintained inside relative humidity at an average level of $85 \%$ ranging approximately between $75 \%$ and $95 \%$. Almost all the transpired water in the closed heat pump system was collected through dehumidification. Water is conserved in the confined system, essentially making the water consumption zero (theoretically speaking). A Tukey Simultaneous Test at a 95\% confidence level confirmed that the difference between conventional and open heat pump systems in transpiration rates was not significant, while the difference between conventional and closed heat pump and between open heat pump and closed heat pump systems were significant (Table 2).

\section{CONCLUSION}

This study showed that how water and energy consumptions inside the greenhouse changed under conventional, open heat pump, and closed heat pump greenhouse systems. Outside environment has the most effect in a conventional system and the least effect in a closed heat pump system. An open heat pump system depends also heavily on the outside weather, but is much better than conventional greenhouses because less energy and water is consumed. A confined system, on the other hand, only uses a heat pump to regulate humidity and temperature within the greenhouse and has slightly higher energy consumption than the open loop heat pump system during summer months. Additional energy is used to provide cooling in this confined system. Results suggest that a 
combination of the closed heat pump and the open heat pump systems has the greatest benefit. That is, the greenhouse should be operated as a semi-closed system in semi-arid California conditions as well, as suggested earlier by Yildiz and Stombaugh (2006b) for higher latitude climates. During the winter and spring months, the greenhouse system would be operated as closed system conserving all the water and consuming much less energy to keep the thermal environment at desirable levels. Closed loop greenhouse operation with a heat pump system would also make it easier to keep high $\mathrm{CO}_{2}$ levels inside the greenhouse, while reducing the risk of insects and diseases within the confined greenhouse environment. During the summer months, however, the greenhouse would be operated as an open system introducing ventilation into the greenhouse, hence allowing outside air to remove excess humidity within the greenhouse and reducing the cooling load over the heat pump.

\section{ACKNOWLEDGEMENTS}

This study was made possible by a grant from the Cal Poly Honors Program and College of Engineering. The authors would also like to extend their appreciation to Mechanical Engineering Department for providing partial funding for the study, and the reviewers for their constructive suggestions.

\section{Literature Cited}

Christensen, R.N. and Santoso, M. 1990. An evaluation of a Rankine cycle driven heat pump. Heat Recovery Systems and CHP. Great Britain. 10(2):161-175.

Ebru, K.A. and Arif, H. 2007. A comparative study on exergetic assessment of two ground-source (geothermal) heat pump systems for residential applications. Building and Environment 42:2004-13

Hamada, Y., Nakamura, M., Saitoh, H., Kubota, H. and Ochifuji, K. 2007. Improved underground heat exchanger by using no-dig method for space heating and cooling. Renewable Energy 32:480-495

Karlsson, F. and Fahle'n, P. 2007. Capacity-controlled ground source heat pumps in hydronic heating systems. International Journal of Refrigeration 30:221-229.

Willits, D.H. and Gurjer, Y.R. 2004. Heat pumps for the heating and night-cooling of greenhouse crops: a simulation study. Transactions of the ASAE 47(2):575-584.

Yildiz, I., Lin, C. and Christensen, R.N. 1993. A performance study of a Rankine cycle driven heat pump system. AES-Vol. 29, Heat Pump and Refrigeration Systems Design, Analysis, and Applications. ASME 1993. USA. p.9-18.

Yildiz, I. and Stombaugh, D.P. 2006a. Dynamic modeling of microclimate and environmental control strategies in a greenhouse coupled with a heat pump system. Acta Hort. 718:331-340.

Yildiz, I. and Stombaugh, D.P. 2006b. Simulated performances of a heat pump system for energy and water conservation in open and confined greenhouse systems. Acta Hort. 718:341-350. 


\section{$\underline{\text { Tables }}$}

Table 1. Greenhouse and crop characteristics used in the simulation model.

\begin{tabular}{ll} 
Greenhouse length & $15.0 \mathrm{~m}$ \\
Greenhouse width & $7.50 \mathrm{~m}$ \\
Greenhouse height at eaves & $2.50 \mathrm{~m}$ \\
Greenhouse height at ridges & $4.50 \mathrm{~m}$ \\
Glazing & Double polyethylene \\
Floor surface material & Reflective mulch; $60 \%$ reflectivity \\
Crop type & Cucumber \\
Crop row orientation & North-South \\
Distance between plant rows & $0.75 \mathrm{~m}$ \\
Leaf length x width & $0.30 \mathrm{x} 0.25 \mathrm{~m}$ \\
Plant height & $2.0 \mathrm{~m}$ \\
\hline
\end{tabular}

Table 2. Comparisons of energy and water consumption means with respect to different greenhouse systems using the Tukey Simultaneous Test at a 95\% confidence level (CON: Conventional System; OHP: Open Heat Pump System; CHP: Closed Heat Pump System).

\begin{tabular}{|c|c|c|c|}
\hline \multicolumn{4}{|c|}{ Total Energy Consumption (all values in $\mathrm{MJ} / \mathrm{m}^{2} /$ day) } \\
\hline System (Mean) & $\begin{array}{l}\text { Compared to } \\
\text { System } \\
\text { (Mean) }\end{array}$ & $\begin{array}{l}\text { Difference } \\
\text { of Means }\end{array}$ & $\begin{array}{c}\text { Statistically } \\
\text { Significant at a } \\
95 \% \text { level? }\end{array}$ \\
\hline \multirow{2}{*}{ CON (19.29) } & OHP (8.85) & 10.45 & YES \\
\hline & CHP (11.20) & 8.09 & YES \\
\hline OHP (8.25) & CHP (11.20) & -2.35 & YES \\
\hline \multicolumn{4}{|c|}{ Water Consumption for Transpiration (all values in $\mathrm{kg} / \mathrm{m}^{2} /$ day) } \\
\hline $\begin{array}{l}\text { System } \\
\text { (Mean) }\end{array}$ & $\begin{array}{l}\text { Compared to } \\
\text { System } \\
\text { (Mean) }\end{array}$ & $\begin{array}{l}\text { Difference } \\
\text { of Means }\end{array}$ & $\begin{array}{c}\text { Statistically } \\
\text { Significant at a } \\
95 \% \text { level? }\end{array}$ \\
\hline \multirow{2}{*}{ CON (2.17) } & OHP (2.25) & -0.08 & NO \\
\hline & CHP (0.99) & 1.18 & YES \\
\hline OHP (2.25) & CHP (0.99) & 1.26 & YES \\
\hline
\end{tabular}




\section{Figures}
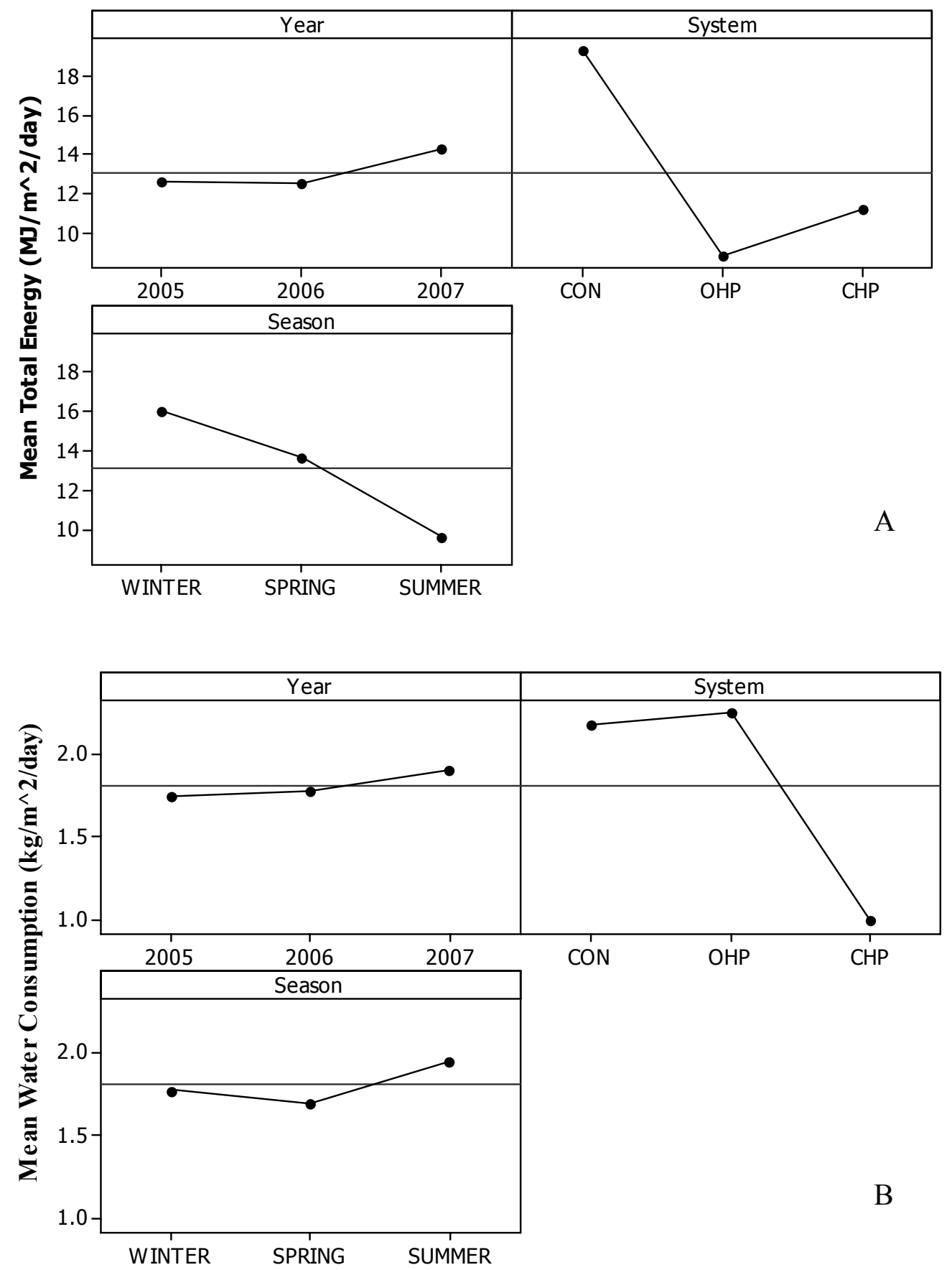

Fig. 1. Mean total energy (A) and mean water consumption for transpiration (B) by each greenhouse system, season and year (CON: Conventional System; OHP: Open Heat Pump System; CHP: Closed Heat Pump System). 